DOI: 10.31866/2617-2674.4.1.2021.235076

UDC 7-028.26'06

\title{
MODERN AUDIOVISUAL ART WITHIN THE SPACE OF INTERNET NETWORK: NEW ASPECTS OF INTERACTION
}

\author{
Oleksandr Bezruchko ${ }^{1 a}$, Olha Anikina ${ }^{2 a}$ \\ ${ }^{1}$ Doctor of Study of Art, PhD in Cinematographic Art, Television, Professor; \\ e-mail: oleksandr_bezruchko@ukr.net; ORCID: 0000-0001-8360-9388 \\ ${ }^{2}$ Master's Student at the Cinema and Television Arts Department; \\ e-mail: knorka1998@gmail.com; ORCID:0000-0003-1546-7036 \\ ${ }^{a}$ Kyiv National University of Culture and Arts, Kyiv, Ukraine
}

Keywords:
audiovisual art;
Internet;
virtual reality;
content;
user control;
medication

For citation:

Bezruchko, O. and Anikina, O. (2021). Modern audiovisual art within the space of Internet network: new aspects of interaction. Bulletin of Kyiv National University of Culture and Arts. Series in Audiovisual Arts and Production, 4(1), pp.43-51. 


\section{Problem statement}

Audiovisual art is at a new stage of development, thanks to the constant development of technology around the fields of cinema and audio recording. By combining high-quality visual and audio components, art demonstrates new levels of technological advancement that allow the user to delve deeper into a product.

With the constant development of technology in the digital sphere, the level of interactivity that the consumer can have with the product of art is constantly increasing. This art form has spread significantly recently due to the development of virtual reality technologies, which allows the viewer to significantly immerse themselves in the visual range because it occupies the entire field of view of the consumer.

At the same time, it cannot be said that this kind of art is widespread within Ukraine, being present only in installation-type projects, where the spectator's interaction with a work of art is often the basis of design.

An important stage of audiovisual art can be considered the period in the twentieth century when cinema gradually ceased to be silent. Thus, with the addition of sound or soundtrack, the film began to have two full-fledged elements: visual and audio.

The evolution of audiovisual art has included increasing the ability to dive deeper into the atmosphere and the very places where this work of art takes place. The development of video games began a new trend when the viewer had the opportunity to be active, interacting with various elements to advance the plot.

Thanks to the gaming industry, people have finally been able to create their version of history, thus, in fact, influ- encing artistic design. Due to this precedent, each passage of the video game is a unique work of art that reflects the personal choices and strategies of the viewer. Everyone who interacts in their way with any truly interactive work of art creates one of its versions: their own.

\section{Recent research and publications analysis}

The beginning of the history of audiovisual art and its development in the initial stages can be assessed by the work of R. Arnheim (1974).

Thanks to the research work of A. Burov and E. Yaremenko (2012), it is possible to understand the evolution of audiovisual art and thought in the context of multimedia language.

L. Briukhovetska (2009) describes the national audiovisual art in the European context, which makes it clearer how a Ukrainian film product can be perceived abroad and how it can be promoted in more effective ways.

V. Didenko's article (2020) will provide a better understanding of how virtual reality, as a subspecies of audiovisual art, helps in the treatment of mental trauma.

Hilko (2004) provides a better understanding of audiovisual culture and, accordingly, better conveys the context of this art form.

The works of J. Hunter (2004) give the perspective of foreign researchers on the subject of research and provides an opportunity to compare the views of both domestic and foreign scholars on audiovisual art.

Primary sources such as short films and video games are also used, which directly illustrate the formats of audiovisual art in an understandable manner. Note that all sources are selected in such a way as to 
provide different perspectives on the art of audiovisual art.

The purpose of the study is to consider the types of modern audiovisual art, to understand its components and the novelty it offers. The article also analyzes the relationship of the audiovisual artist with the audience, along with new aspects of consumer interaction and artistic content. It is necessary to understand the impact of this art form on human consciousness and what changes audiovisual art brings to long-known forms, such as movies or video games.

\section{Main research material}

Audiovisual art, in addition to the above-mentioned period of its actual appearance, received a powerful impetus in the form of virtual technology. The latest reality uses a special device that broadcasts a 3D video. This uses headphones that allow the content consumer to fully immerse themselves in virtual reality. Given the constant improvement and progress in the field of devices for broadcasting VR content and the emergence of appropriate cameras, there has been a significant increase in the number of films that can be viewed in $360^{\circ}$ format. Such films are shot with the expectation that the viewer will constantly look in different directions during the action set by the film crew, led by the director.

The evolution of audiovisual art leads to a different perception of cinema. First, virtual technologies will enhance certain aspects that are commonly associated with the audiovisual arts, namely the audio component as a reflective component, as well as sound and visual images, which according to M. Khilko (2000, p.14) are essential components of audiovisual art. The significance of sound and visual images will increase as viewers become more immersed in the middle of the movie scenes that will emerge during the unfolding of the plotline of the audiovisual work.

The construction of virtual space within the cinematic specifics is not new. J. Siemens (2007, p.125) in the article Between Cinema and the Computer cites the works of Lars von Trier in Element of Crime and Europe, in which completely virtual worlds are constructed, constructed by lighting effects and physically impossible relationships between time and space. Cinema, at its core, usually constructs a virtual space that is a reality within a screen and a certain amount of time. Virtual reality and 360-degree shooting raise the concept of immersion to another level because instead of the operator, the viewer himself becomes responsible for their angles and what is in his field of vision. The ability to look anywhere in a particular location, significantly reduces the so-called fourth wall, because it is in fact in the middle of the viewer, who is contemplating the film product from the inside.

The first attempts to immerse the viewer in the film as much as possible began with the use of the 3D format to enhance the visual component. However, the point of view in the cinema remains the same for the viewer. With virtual reality, the perspective can be constantly changed and done fairly quickly. Currently, you can watch a large number of horror movies in this area, as the goal is to bring the viewer into a state of fear. An example is the short film IT: Float - A Cinematic VR Experience. While the viewer in the virtual reality device looks in one direction, thanks to a wide panorama of sound, he can hear the sound behind, turn around and see prepared for this moment jump 
scare - an unexpected moment of intimidation. The viewer first looks at one end of the tunnel, hears thunder and sees lightning, which is a trigger for the appearance of the clown Pennywise behind. The spectator turns slowly and sees a red ball floating slowly towards him, followed by the antagonist himself. At the same time, the viewer may not turn around, look in the opposite direction and thus miss the so-called classic jump scare. This case vividly illustrates how a person can change it in real-time, thus sometimes not following the artistic intentions of the creators of this audiovisual work of art. The responsibility for a large number of creative plot choices rests with the viewer.

Another extremely important form of modern audiovisual art is the video game, primarily created with VR technology in mind. Games in the format of virtual reality are constantly gaining popularity. At the beginning of the 21st century, these were short sketches to demonstrate the possibilities of new technology. Beginning in 2010, the quality and scale of works of art began to grow significantly when leading studios released so-called AAA games (games of the best quality and extraordinary scale with appropriate graphics) purely in VR format, not releasing them for other, more common platforms.

As noted by E. Salnikov (2012, p.21) in the online article "The phenomenon of visuality and the evolution of visual culture", games are a separate interesting art format because they can offer not only entertainment but also aesthetic pleasure in certain contexts. Creating 3D games in the 90 s of the twentieth century significantly expanded the capabilities of this format. 3D stereoscopic effects began to embody the desire of visual mat- ter to overcome the plane of the ordinary screen and make a breakthrough into the environment surrounding the individual, namely the three-dimensional reality that spontaneously unfolds around the perceiving subject.

Games can be perceived as an audiovisual product and a work-concept studied by V. Poznin in the book "Audiovisual product: technology plus creativity", where he notes that "the nature of audiovisual creativity is determined by the technology of image and sound processing plus the creative potential of a person who is fluent in them" Poznin, (2006, p.10).

According to Bornstein (2009, p.27), virtual reality has the following efforts in its nature: to create space, which is determined by a strong psychological component; to establish space outside the physical framework of space-time and matter and also create an ontological basis for their created reality. It is worth noting the opinion of B. Laurel (1995, p.90), who noted that virtual reality gives people the opportunity to behave differently from reality. Games expand this behaviour, thus giving people a chance to become someone else, which in fact creates a constant demand for games and their ability to create a simulation of another life, which can sometimes be close to real.

Game L. A. Noire: The VR Case Files allows the player to watch a movie and at the same time act as a detective. Although it is not a cinema but the player has an opportunity to fully interact in addition to the ability to explore their environment. This also includes the ability to control the hands and movements of the character, interact with objects such as firearms, choose different strategies for interrogating suspects, drive a car and more. Accordingly, the game can be considered as a work of art. The artist is 
a studio developer led by the main game designers. The player acts as a consumer of the art product. From this division of roles, there is an interesting conclusion that the consumer also acts as an artist. Most games, including the aforementioned $L$. A. Noire, offer various finals, one of which the player goes through a chain of choices during the passage of the storyline. Accordingly, each player creates a unique experience of passing the game, which may not be similar to the experience of other players.

The game Half-Life: Alyx is one of the first large-scale games, which was created specifically for the VR platform. The player is allowed to take part in fights, explore, experience the elements of horror in the city, bypass gravity to get to the destination in an unusual way, interact with a large number of physical objects, and more. The plot is added to the interesting gameplay mechanics, the acting is reflected through motion capture technology, soundtrack, and deeply developed sound design. At the same time, the level of interaction is the deepest. You can take almost all the small objects that catch the eye, and deal with opponents by improvised means. The player not only builds his plot, but also his style of play, thus not only gaining his unique experience, but also his audiovisual work of art and the style of its creation.

There are simpler projects like SUPER HOT (SUPERHOT Team, 2017), which is a regular shooter with some changes in mechanics, such as stopping time when stopping, which gives the shootout elements of strategy. This game has an element of interaction with physical objects and subjects. But thanks to simple graphics, it looks less impressive, but this game can be considered a work of art, where each player creates his experi- ence through different choices and style of play.

Due to the material studied above, we have highlighted the following components of successful examples of virtual reality as part of audiovisual art:

1. deep immersion in a work of art because of the greatest possible isolation from the real world;

2. giving the viewer the choice to form a work of art, making decisions on their own, while providing real alternative plot developments, rather than choosing "without choice";

3. high level of interaction with audiovisual art;

4. high-level visual component and audio design to improve the process of immersion in a work of art.

When the influence of audiovisual art on human consciousness can be noted the great potential of art in the medical field. The following are ways in which a person can treat both mental injuries and undergo physical rehabilitation.

The development of technology has led to the fact that art is almost for the first time officially recognized as an ef fective therapeutic tool, thus creating the first case of the existence of works of art that not only bring aesthetic pleasure but also heal the mind. Since virtual technology allows a person to immerse themselves in a virtual environment, new means of improving mental well-being have become possible. In the context of medicine, as stated in the article "The language of multimedia. The evolution of the screen and audiovisual thinking" (Burov and Yaremenko, 2012, p.85), audiovisual art can be considered as a language of multimedia, the evolution of the screen and audiovisual thinking.

As noted in G. Hunter's article (2004, p.62) "Virtual Reality Therapy", by creating 
a certain audiovisual picture that reproduces a traumatic episode from the past in a fairly realistic manner, a person has the opportunity to look at a terrible event from another point of view vision in an effort to comprehend and accept what has happened. This is exactly the strategy used with the victims of the terrorist attacks in Israel and Spain. Gradually showing the survivors of the attack a realistic picture and the sounds of a bus bomb explosion, the virtual reality program thus helped people relive the tragedy to cope with the extraordinary emotions left after such an experience.

V. Didenko (2019, p.1) in the article "VR in medicine: how the latest technologies help" notes that virtual reality can be used as a stimulant of negative feelings to enable a person to understand what happened, to guess the event that caused the injury, more clearly. Accordingly, we have an interesting case where can significantly stimulate the human mind in order to improve its well-being. Besides, it helps to treat not only psychological trauma but also to conduct cognitive rehabilitation to restore brain functions that are responsible for the perception, processing and analysis of information coming to us from the outside world after a patient has suffered, for example, a stroke.

Virtual reality becomes a product thanks to which a person can not only remember better but also accelerate their learning, make hand movements in the presence of interactive elements. Thus, the following means of virtual reality can be interpreted as examples of interactive art such as installations, where the viewers is invited to either interact with the subject or bring his/her concept to the audiovisual work. In this context, interactivity is conditioned by the need to rehabili- tate patients. Virtual reality can be used not only as an art but also as a medical method that can facilitate communication between doctor and patient (Greifeld, 2009, p.234).

Audiovisual art has the potential to become an effective source of psychological therapy. The better the immersion factor is, the care will be more effective because patients will be able to relive events from the past or immerse themselves in the reality and state of mind they need more accurately. The influence of audiovisual art is possible due to the perceptual and intellectual levels at which the same mechanisms operate as concepts, judgments, logic, abstraction, conclusion, calculation, etc. (Arnheim, 1974, p.12).

\section{Conclusions}

We have been able to identify the most important components of virtual reality's successful examples in the art of audiovisual art. Specific modern examples of various forms of this art have been analyzed. The modified role of the consumer of an art product has been considered because the choice is more often given to the spectator and he gets the freedom to make a choice and have his own unique experience with a game or film shot in 360-degree mode.

The influence of audiovisual art on human consciousness and the possibility of such influence's practical application in the treatment of injuries of various origins have been considered.

There are various scientific views on this art, which include the ideas of both domestic and foreign researchers, using works from different years to explore how human perceptions of audiovisual art have changed over the past decades. 


\section{REFERENCES}

Arnkheim, R., 1974. Iskusstvo i vizualnoe vospriiatie [Art and visual perception]. Moscow: Progress

Botz-Bornstein, T., 2009. Virtual Reality and Virtual Irreality On Noh-Plays and Icons. Pravmir. com. [online] Available at: <http://www.pravmir.com/article_812.html> [Accessed 10 May 2020]. Burov, A. and laremenko, E., 2012. lazyk multimedia. Evoliutciia ekrana $i$ audiovizualnogo myshleniia [The Language of Multimedia. Evolution of the screen and audiovisual thinking]. [online] Moscow. Available at: <http://mkrf.ru/upload/mkrf/mkdocs2012/08_11_2012_4.pdf> [Accessed 10 May 2020].

Didenko, V., 2019. VR v medytsyni: yak dopomahaiut novitni tekhnolohii [VR in medicine: how the latest technologies help]. Patriot Defence All rights reserved. [online] Available at: <https:// patriotdefence.org/brainteka/u-sviti/vr-v-mediczini-yak-dopomagayut-novitni-texnologiyi. html> [Accessed 10 May 2020].

Valve, 2020. Half-Life: Alyx. Steam. [online] Available at: <https://store.steampowered.com/ app/546560/HalfLife_Alyx/> [Accessed 10 May 2020].

Warner Bros. Pictures, 2017. IT: FLOAT - A Cinematic VR Experience. YouTube. [online] Available at: <https://youtu.be/FHUErvVAelw> [Accessed 10 May 2020].

Rockstar Games. 2019. L.A. Noire: The VR Case Files. Steam. [online] Available at: <https://store. steampowered.com/app/722230/LA_Noire_The_VR_Case_Files/> [Accessed 10 May 2020].

Laurel, B., 1995. Virtual Reality. Scientific American, 273 (3), p.90.

Poznin, V., 2006. Audiovizualnyi produkt: tekhnologiia plius tvorchestvo [Audiovisual Product: Technology Plus Creativity]. St. Petersburg: St. Petersburg State University of Film and Television. Salnikova, E., 2012. Fenomen vizualnosti i evoliutciia vizualnoi kultury [The phenomenon of visuality and the evolution of visual culture]. Ph.D. thesis. The State Institute for Art Studies. Cheloveknauka.com. [online] Available at: <http://cheloveknauka.com/v/356029/d\#?page=1> [Accessed 10 May 2020].

Simons, J., 2007. Between Cinema and Computer. In: Playing the Waves: Lars von Trier's Game Cinema. Amsterdam: Amsterdam University Press, pp.125-154.

SUPERHOT Team, 2017. SUPERHOT VR. Steam. [online] Available at: <https://store. steampowered.com/app/617830/SUPERHOT_VR/> [Accessed 10 May 2020].

Hoffman, H.G., 2004. Virtual-reality therapy. Scientific American, [online] 291 (2), pp.58-65. Available at: <http://www.hitl.washington.edu/research/vrpain/index_files/SCIAMFin.pdf > [Accessed 10 May 2020].

Khilko, N., 2000. Audiovizualnaia kultura [Audiovisual culture]. Omsk: Izdatelstvo Omskogo gosudarstvennogo universiteta. 


\section{СУЧАСНЕ АУДІОВІЗУАЛЬНЕ МИСТЕЦТВО В ПРОСТОРАХ МЕРЕЖІ ІНТЕРНЕТ: НОВІ АСПЕКТИ ВЗАЄМОДІЇ}

\section{Олександр Безручко1a ${ }^{1}$ Ольга Анікіна2а}

${ }^{1}$ доктор мистецтвознавства, професор;

e-mail: oleksandr_bezruchko@ukr.net; ORCID: 0000-0001-8360-9388

${ }^{2}$ магістрант кафедри кіно-, телемистецтва;

e-mail: knorka1998@gmail.com; ORCID: 0000-0003-1546-7036

а Київський національний університет культури і мистецтв, Київ, Україна

\section{Анотація}

Мета дослідження - висвітлити види сучасного аудіовізуального мистецтва, встановити його компоненти і новизну разом з його впливом на сучасні мистецькі тренди. В статті також проаналізовано взаємини аудіовізуального митця з аудиторією разом з новими аспектами взаємодії споживача і мистецького контенту. Необхідно зрозуміти вплив цього виду мистецтва на людську свідомість і те, які зміни приносить з собою аудіовізуальне мистецтво стосовно давно відомих форм, таких як кінокартини чи відеоігри. Методологія дослідження полягає у застосуванні таких методів: теоретичний (розгляд наукових статей, які проводять дискусію щодо аудіовізуального мистецтва у теоретичному ключі) і емпіричний (розгляд і аналіз різних медіаматеріалів для отримання інформації по найбільш релевантних і нещодавніх витворах аудіовізуального мистецтва). Наукова новизна полягає в детальному аналізі компонентів аудіовізуального мистецтва, враховуючи, що в просторі української наукової думки цей вид мистецтва ще не досліджується повсюдно. Висновки. У процесі дослідження було встановлено основні риси аудіовізуального мистецтва, докладно розглянуто відносини і взаємодії аудіовізуального митця і його аудиторії разом зі змінами у ролі споживача мистецтва і ступеня контролю споживача над художнім замислом. Встановлена можливість використання аудіовізуального мистецтва як терапевтичного засобу для лікування ментальних травм.

Ключові слова: аудіовізуальне мистецтво; мережа Інтернет; віртуальна реальність; контент; контроль споживача; лікування 


\title{
СОВРЕМЕННОЕ АУДИОВИЗУАЛЬНОЕ ИСКУССТВО В ПРОСТОРАХ СЕТИ ИНТЕРНЕТ: НОВЫЕ АСПЕКТЫ ВЗАИМОДЕЙСТВИЯ
}

\author{
Александр Безручкоa, Ольга Аникина'²а \\ ${ }^{1}$ доктор искусствоведения, профессор; \\ e-mail: oleksandr_bezruchko@ukr.net; ORCID: 0000-0001-8360-9388 \\ ${ }^{2}$ магистрант кафедры кино-, телеискусства; \\ e-mail: knorka1998@gmail.com; ORCID: 0000-0003-1546-7036 \\ а Киевский национальный университет культуры и искусств, Киев, Украина
}

\begin{abstract}
Аннотация
Цель исследования - осветить виды современного аудиовизуального искусства, понять его компоненты и новизну, которую оно предлагает. В статье также проанализированы взаимодействия аудиовизуального творца с аудиторией вместе с новыми аспектами взаимодействия потребителя и художественного контента. Более того, необходимо понять влияние этого вида искусства на человеческое сознание и то, какие изменения аудиовизуальное искусство привносит с собой в давно известные формы, такие как кинокартины и видеоигры. Методология исследования состоит в использовании таких методов: теоретический (рассмотрение научных статей, которые проводят дискуссию касательно аудиовизуального искусства в теоретической плоскости) и эмпирический (рассмотрение и анализ различных медиаматериалов для получения информации по наиболее свежим продуктам аудиовизуального искусства). Научная новизна заключается в подробном анализе компонентов аудиовизуального искусства, учитывая, что в пространстве украинской научной мысли этот вид искусства еще не исследуется повсеместно. Выводы. В ходе исследований были установлены основные черты аудиовизуального искусства, подробно рассмотрены отношения и взаимодействия аудиовизуального творца с его аудиторией и степень контроля потребителя над художественным замыслом. Статья также установила возможность использования аудиовизуального искусства в качестве терапевтического метода для лечения ментальных травм.
\end{abstract}

Ключевые слова: аудиовизуальное искусство; сеть Интернет; виртуальная реальность; контент; контроль потребителя; лечение 